\title{
Assessment of Radionuclide Concentrations and Absorbed Dose from Consumption of Community Water Supplies in Oil and Gas Producing Areas in Delta State, Nigeria
}

\author{
Pascal Tchokossa $^{1 *}$, James Bolarinwa Olomo ${ }^{1}$, Fatai Akintunde Balogun ${ }^{2}$ \\ ${ }^{1}$ Department of Physics, Obafemi Awolowo University, Ile-Ife, Osun State, Nigeria \\ ${ }^{2}$ Centre for Energy Research and Development, Obafemi Awolowo University, Ile-Ife, Osun State, Nigeria \\ E-mail: ptchokos@yahoo.com
}

Received April 23, 2011; revised June 25, 2011; accepted August 9, 2011

\begin{abstract}
A survey of radioactivity concentration in water supplies used for domestic and industrial purposes in the oil and gas producing communities of Delta State, Nigeria was carried out using a well-calibrated High-Purity Germanium (HPGe) detector system. The study area was partitioned into ten sections and a total of two samples per partition were collected for analysis. Samples of water from a non-producing area were also collected as control. In all, a total number of forty three samples were collected and analyzed. Each sample was acidified at the rate of $10 \mathrm{ml}$ of $11 \mathrm{M} \mathrm{HCl}$ per liter of water to prevent the absorption of radionuclides into the wall of the container and sealed in a properly cleaned container for at least one month so as to attain a state of secular radioactive equilibrium before analysis. The photopeaks observed with reliable regularity belong to the naturally occurring series-decay radionuclide headed by ${ }^{238} \mathrm{U}$ and ${ }^{232} \mathrm{Th}$, as well as the non-series decay type ${ }^{40} \mathrm{~K}$. The mean specific activity obtained for ${ }^{40} \mathrm{~K}$ was $49 \pm 15 \mathrm{~Bq} \cdot \mathrm{L}^{-1}$ with a range of 6 $177 \mathrm{~Bq} \cdot \mathrm{L}^{-1}$ while for ${ }^{238} \mathrm{U}$, the mean specific activity was $3 \pm 1 \mathrm{~Bq} \cdot \mathrm{L}^{-1}$ with a range of $1-12 \mathrm{~Bq} \cdot \mathrm{L}^{-1}$ and the mean specific activity for ${ }^{232} \mathrm{Th}$ was $3 \pm 2 \mathrm{~Bq} \cdot \mathrm{L}^{-1}$ with a range of $2-10 \mathrm{~Bq} \cdot \mathrm{L}^{-1}$ and the total annual effective dose, which vary between $0-2 \mu \mathrm{Sv} \cdot \mathrm{y}^{-1}$, did not show any significant health impact.
\end{abstract}

Keywords: Radioactivity, Doses, Water, Gamma Spectroscopy, Oil Areas, Nigeria

\section{Introduction}

Water is an essential commodity without which there is no life. Radionuclides are present in the air breathed by man, in food and drinking water [1-3] consumed by man and in the ground from which human settlements are built [4]. Enhanced levels of uranium, thorium and their daughter products might be present in water in area that is rich in natural radioactivity or through human activities. The dumping of large amount of waste materials in sites without adequate soil protection measures result in soil as well as, surface and ground water pollution $[5,6]$. As groundwater moves through fractures in the bedrock that contain these deposits, radioactive minerals can leach out into ground-water system. Contaminants from human activities pass into air, soil and water, and, hence into fish crops and other animals [7]. The input of radionuclide such as K-40 to the environment is derived from terrestrial soil and atmospheric diffusion $[8,9]$. Con- sidering the high radiotoxicity of ${ }^{226} \mathrm{Ra}$ and ${ }^{228} \mathrm{Ra}$, their presence in water and the associated health risks require particular attention. Radionuclides when ingested or inhaled enter the human body and are distributed among body organs according to the metabolism of the element involved. The organs normally exhibit varying sensitivities to the radiation and thus, varying does and risks result from their consumption or inhalation. UNSCEAR [10,11], Mettler and Sinclair [12] estimated that, terrestrial sources are responsible for most of man's exposure to natural radiation, most of it by internal radiation, with cosmic rays contributing just under half of man's exposure to external radiation. Accurate estimation of the occurrence of radionuclide in community water will provide information from which estimates of average radiation exposures of the public from these sources in some oil and gas producing areas in Delta State can be made.

Radioactivity and radiation levels in various environmental samples have been of great concern in many 
countries [13,14]. Cothern and Lappenbush [15] and Cothern et al., [16] reported the occurrence of uranium in drinking water in the United State of America. Other workers [17-20] published obtained data from monitoring community drinking water in various countries. Other researchers have investigated radon levels in the water [21] in some regions of Poland.

Here in Nigeria, Olomo et al., [22] reported their findings on the mean specific activities in soil and water around some nuclear establishment in Ile-Ife; while Tchokossa et al. [23] reported the results of measurements of naturally occurring radionuclide concentrations in the community water supplies in two local government areas in Ile-Ife Osun State.

\section{Materials and Methods}

The study area was partitioned into ten sections and a total of two samples were collected for analysis from each partition. Samples of water from a non-producing area were collected as control. In all, a total number of forty three samples were collected and analyzed. The study area covers the entire Delta State and the samples locations are as listed in Table 1 and shown on Figure 1. The sampling locations were based on factors such as population density, farm settlements, educational institutions, hospitals etc., especially the commonly used water type around oil and gas producing areas. The type of water collected were well water, tap water, drinkable surface water, non-drinkable surface water, freely falling rain water, rain water falling through aluminum sheets and rain water falling through asbestos sheets.

Well water, tap water, rain water, surface water were collected as may be appropriate from their sources as for instance tap water was collected at the water processing (filtration/purification) plants just prior to discharge into the distribution system or if in a residence, the pipes were flushed sufficiently prior to sample collection while rain water was collected with the aid of a rain collector previously washed with dilute acid $(0.1 \mathrm{M} \mathrm{HCl})$ and located on the roofs of buildings to avoid contamination by airborne soil and surface dust. Surface water samples from streams were collected directly from the stream using a 1 liter plastic keg. Well water was collected directly from

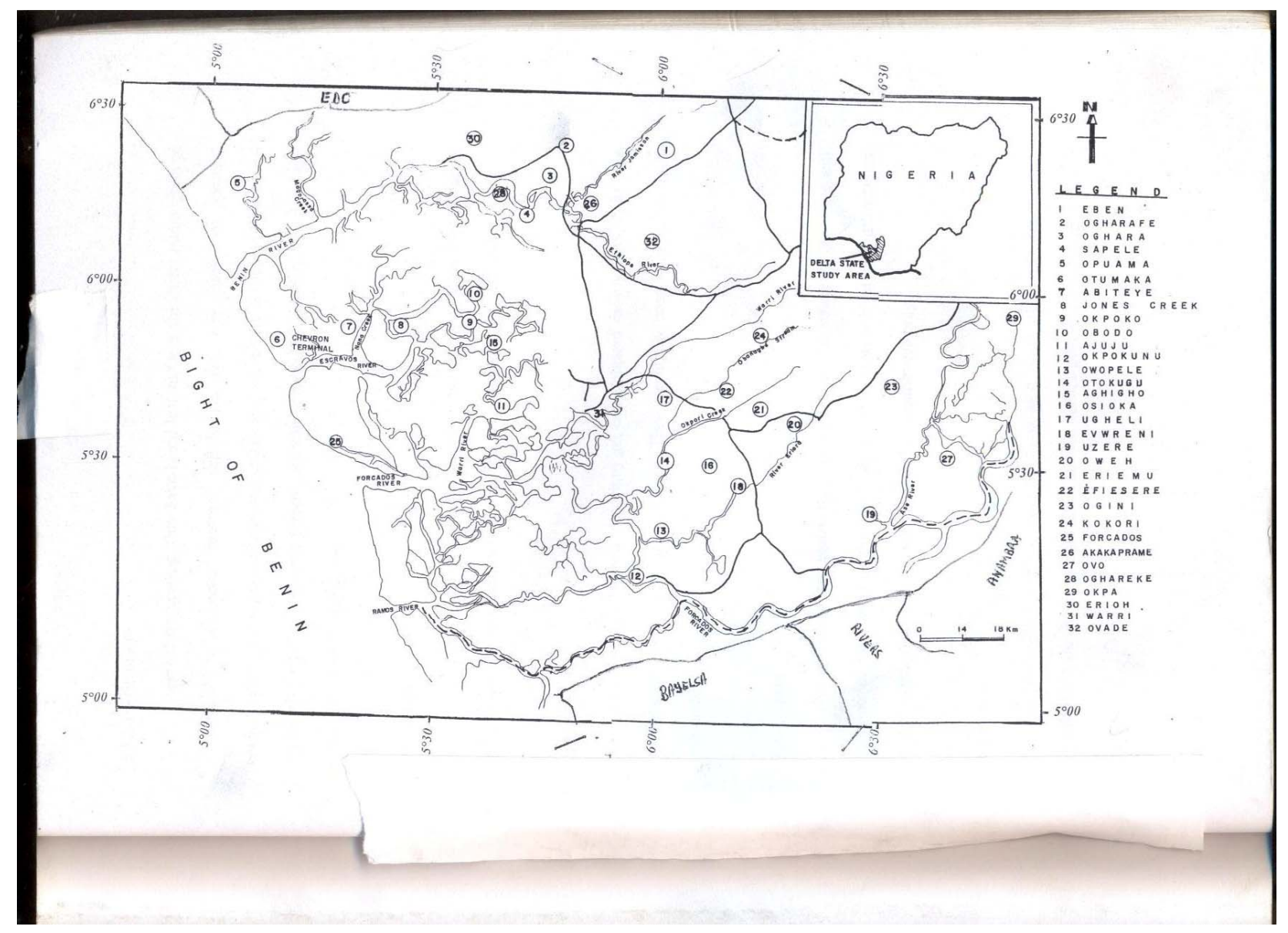

Figure 1. Map of the study area. 
Table 1. Geology and locations of the sampling points.

\begin{tabular}{|c|c|c|c|c|}
\hline \multirow{2}{*}{ Sample No } & \multirow{2}{*}{ Name of the Town } & \multirow{2}{*}{ Brief Geology of Sampling Point } & \multicolumn{2}{|c|}{ Location } \\
\hline & & & Longitude & Latitude \\
\hline 1 & Oben & Sandstones & $6^{\circ} 01^{\prime} 16^{\prime \prime} \mathrm{E}$ & $5^{\circ} 53^{\prime} 5^{\prime \prime} \mathrm{N}$ \\
\hline 2 & Ogharefe & Sandstones, siltstones & $601^{\prime} 17^{\prime \prime} \mathrm{E}$ & $5^{\circ} 41^{\prime} 47^{\prime \prime} \mathrm{N}$ \\
\hline 3 & Oghara & Sand, siltstones & $5^{\circ} 56^{\prime} 25^{\prime \prime} \mathrm{E}$ & $5^{\circ} 40^{\prime} 21 " \mathrm{~N}$ \\
\hline 4 & Sapele & Sand, siltstones & $5^{\circ} 53^{\prime} 55^{\prime \prime} \mathrm{E}$ & $5^{\circ} 37^{\prime} 08^{\prime \prime} \mathrm{N}$ \\
\hline 5 & Opuama & Sand, gravel, clay & $5^{\circ} 55^{\prime} 42^{\prime \prime} \mathrm{E}$ & $5^{\circ} 04^{\prime} 21 " \mathrm{~N}$ \\
\hline 6 & Otumaka & Sand, gravel, clay & $5^{\circ} 39^{\prime} 3 " \mathrm{E}$ & $5^{\circ} 09^{\prime} 17 " \mathrm{~N}$ \\
\hline 7 & Abiteye & Sand, Sandstones & $5^{\circ} 40^{\prime} 54^{\prime \prime} \mathrm{E}$ & $5^{\circ} 17^{\prime} 19^{\prime \prime} \mathrm{N}$ \\
\hline 8 & Jones Creek & Sand, Sandstones & $5^{\circ} 41^{\prime} 15^{\prime \prime} \mathrm{E}$ & $5^{\circ} 23^{\prime} 27^{\prime \prime} \mathrm{N}$ \\
\hline 9 & Okpoko & Sand, gravel, clay & $5^{\circ} 41^{\prime} 47^{\prime \prime} \mathrm{E}$ & $5^{\circ} 31^{\prime} 4 " \mathrm{~N}$ \\
\hline 10 & Obodo & Sand, gravel, clay & $5^{\circ} 45^{\prime} 0^{\prime \prime} \mathrm{E}$ & $5^{\circ} 31^{\prime} 25^{\prime \prime} \mathrm{N}$ \\
\hline 11 & Ajuju & Sand, gravel & $5^{\circ} 31^{\prime} 53^{\prime \prime} \mathrm{E}$ & $5^{\circ} 35^{\prime} 0^{\prime \prime} \mathrm{N}$ \\
\hline 12 & Okpokunu & Sand subordinate silt & $5^{\circ} 11^{\prime} 49^{\prime \prime} \mathrm{E}$ & $5^{\circ} 50^{\prime} 54^{\prime \prime} \mathrm{N}$ \\
\hline 13 & Owopele & Sand subordinate silt & $5^{\circ} 17^{\prime} 49^{\prime \prime} \mathrm{E}$ & $5^{\circ} 53^{\prime} 38^{\prime \prime} \mathrm{N}$ \\
\hline 14 & Oturugu & Sand, siltstones & $5^{\circ} 25^{\prime} 32 " \mathrm{E}$ & $5^{\circ} 53^{\prime} 16^{\prime \prime} \mathrm{N}$ \\
\hline 15 & Aghigho & Sand, gravel, clay & $5^{\circ} 39^{\prime} 26 " \mathrm{E}$ & $5^{\circ} 33^{\prime} 55^{\prime \prime} \mathrm{N}$ \\
\hline 16 & Osioka & Sand, siltstones & $5^{\circ} 24^{\prime} 49^{\prime \prime} \mathrm{E}$ & $5^{\circ} 58^{\prime} 53^{\prime \prime} \mathrm{N}$ \\
\hline 17 & Ugheli & Sand, gravel & $5^{\circ} 32^{\prime} 38^{\prime \prime} \mathrm{E}$ & $5^{\circ} 53^{\prime} 49^{\prime \prime} \mathrm{N}$ \\
\hline 18 & Evwreni & Sand, siltstones & $5^{\circ} 23^{\prime} 2 " \mathrm{E}$ & 602'19" N \\
\hline 19 & Uzeke & Sand, subordinate silt & $5^{\circ} 19^{\prime} 49^{\prime \prime} \mathrm{E}$ & $6^{\circ} 16^{\prime} 54^{\prime \prime} \mathrm{N}$ \\
\hline 20 & Oweh & Sand, Sandstones & $5^{\circ} 29^{\prime} 49^{\prime \prime} \mathrm{E}$ & $6^{\circ} 08^{\prime} 23^{\prime \prime} \mathrm{N}$ \\
\hline 21 & Eriemu & Sand, gravel & $5^{\circ} 31^{\prime} 15^{\prime \prime} \mathrm{E}$ & $6^{\circ} 04^{\prime} 6^{\prime \prime} \mathrm{N}$ \\
\hline 22 & Afiesere & Sand, gravel & $5^{\circ} 33^{\prime} 23^{\prime \prime} \mathrm{E}$ & 6001'15" N \\
\hline 23 & Ogini & Sand, Sandstones & $5^{\circ} 34^{\prime} 43^{\prime \prime} \mathrm{E}$ & $6^{\circ} 19^{\prime} 17^{\prime \prime} \mathrm{N}$ \\
\hline 24 & Kokori & Sand, Sandstones & $5^{\circ} 39^{\prime} 37^{\prime \prime} \mathrm{E}$ & $6^{\circ} 03^{\prime} 45^{\prime \prime} \mathrm{N}$ \\
\hline 25 & Forcados & Sand subordinate silt & $5^{\circ} 20^{\prime} 53^{\prime \prime} \mathrm{E}$ & $5^{\circ} 27^{\prime} 16^{\prime \prime} \mathrm{N}$ \\
\hline 26 & Akpaprame & Sand, Sandstones & $5^{\circ} 54^{\prime} 49^{\prime \prime} \mathrm{E}$ & $5^{\circ} 40^{\prime} 57^{\prime \prime} \mathrm{N}$ \\
\hline 27 & Ovo & Sand, Sandstones & $5^{\circ} 27^{\prime} 27^{\prime \prime} \mathrm{E}$ & $6^{\circ} 25^{\prime} 20^{\prime \prime} \mathrm{N}$ \\
\hline 28 & Oghareke & Sand, Sandstones & $5^{\circ} 55^{\prime} 48^{\prime \prime} \mathrm{E}$ & $5^{\circ} 35^{\prime} 28^{\prime \prime} \mathrm{N}$ \\
\hline 29 & Okpa & Sand, Sandstones & $5^{\circ} 42^{\prime} 08^{\prime \prime} \mathrm{E}$ & $6^{\circ} 32^{\prime} 40^{\prime \prime} \mathrm{N}$ \\
\hline 30 & Enioh & Sandstones siltstones & $6^{\circ} 32^{\prime} 17^{\prime \prime} \mathrm{E}$ & $5^{\circ} 30^{\prime} 45^{\prime \prime} \mathrm{N}$ \\
\hline 31 & Warri & Sand gravel & $5^{\circ} 30^{\prime} 45^{\prime \prime} \mathrm{E}$ & $5^{\circ} 46^{\prime} 25^{\prime \prime} \mathrm{N}$ \\
\hline 32 & Ovade & Sand, Sandstones & $5^{\circ} 48^{\prime} 45^{\prime \prime} \mathrm{E}$ & $5^{\circ} 48^{\prime} 12^{\prime \prime} \mathrm{N}$ \\
\hline 33 & Jamieson river & Coarse sand & $6^{\circ} 00^{\prime} 32^{\prime \prime} \mathrm{E}$ & $5^{\circ} 46^{\prime} 5^{\prime \prime} \mathrm{N}$ \\
\hline 34 & Ethiope river & Coarse sand & $5^{\circ} 47^{\prime} 30^{\prime \prime} \mathrm{E}$ & $5^{\circ} 48^{\prime} 45^{\prime \prime} \mathrm{N}$ \\
\hline 35 & Warri river & Sandstones & $5^{\circ} 30^{\prime} 33^{\prime \prime} \mathrm{E}$ & $5^{\circ} 32^{\prime} 08^{\prime \prime} \mathrm{N}$ \\
\hline 36 & Eriora river & Coarse sand & $5^{\circ} 28^{\prime} 12^{\prime \prime} \mathrm{E}$ & $6^{\circ} 08^{\prime} 55^{\prime \prime} \mathrm{N}$ \\
\hline 37 & Aso river & Sandstones & $5^{\circ} 20^{\prime} 43^{\prime \prime} \mathrm{E}$ & $6^{\circ} 20^{\prime} 10^{\prime \prime} \mathrm{N}$ \\
\hline
\end{tabular}


the wells using a manual procedure for collecting water from deep or shallow wells. All the storing containers were previously washed with dilute acid $(0.1 \mathrm{M} \mathrm{HCl})$, and water samples were acidified with $11 \mathrm{M}$ of $\mathrm{HCl}$ at the rate of $10 \mathrm{ml}$ per litre of sample immediately after sampling to avoid absorption of radionuclide on the walls of the container. The storage time was at least 28 days for the state of secular equilibrium to be reached among the daughter products of ${ }^{228} \mathrm{U}$ and ${ }^{232} \mathrm{Th}$. The gamma-counting equipment was a Canberra vertical Highpurity coaxial germanium (HPGe) crystal detector, model GC2018-7500, Serial No b 87063 enclosed in a 100mm lead shied and coupled to a Canberra Multichannel Analyzing (MCA) computer system. The quantification of radionuclide present in water samples was obtained through accurate energy and efficiency calibration using a well calibrated standard water sources supplied by the International Atomic Energy Agency (IAEA), Vienna, Austria. The techniques used are well described elsewhere [24]. The MCA was calibrated so as to display gamma photopeaks in the energy range of 200-3000 keV, this being the energy range for radionuclides of interest identified with reliable regularity. The counting time was 36,000 s. An empty container identical to that of the sample was also counted for the same counting time under the same geometry to determine the background distribution spectrum. The photopeaks observed with reliable regularity belong to the naturally occurring series-decay radionuclide headed by ${ }^{238} \mathrm{U}$ and ${ }^{232} \mathrm{Th}$, as well as the non-series decay type ${ }^{40} \mathrm{~K}$. The activities of radionuclide were calculated from the difference between net peakand net peak background areas, accumulation time, absolute peak efficiency, absolute $\gamma$-ray emission probability and the sample volume. Measurement of radionuclide concentrations in the water sample were carried out at least twice to check on the reproducibility of results and the stability of the counting system. The overall uncertainty in the measured concentrations was estimated using the procedure already described in an earlier work [23].

\section{Result and Discussion}

\subsection{Radioactivity Content in Water}

The specific activities measured in the various types of water are reported in Table 2 and Figure 2.

The activity concentration of ${ }^{40} \mathrm{~K}$ ranged from 46 - 98 $\mathrm{Bq} \cdot \mathrm{L}^{-1}$ with an average of $67 \pm 21 \mathrm{~Bq} \cdot \mathrm{L}^{-1}$ for well water; $12-32 \mathrm{~Bq} \cdot \mathrm{L}^{-1}$ with an average of $22 \pm 12 \mathrm{~Bq} \cdot \mathrm{L}^{-1}$ for tap water; $7-177 \mathrm{~Bq} \cdot \mathrm{L}^{-1}$ with an average of $74 \pm 24 \mathrm{~Bq} \cdot \mathrm{L}^{-1}$ for non drinkable surface water; $6-76 \mathrm{~Bq} \cdot \mathrm{L}^{-1}$ with an average of $36 \pm 13 \mathrm{~Bq} \cdot \mathrm{L}^{-1}$ for drinkable surface water; 28
- $41 \mathrm{~Bq} \cdot \mathrm{L}^{-1}$ with an average of $34 \pm 12 \mathrm{~Bq} \cdot \mathrm{L}^{-1}$ for freely falling rain water; $29-46 \mathrm{~Bq} \cdot \mathrm{L}^{-1}$ with an average of $38 \pm$ $10 \mathrm{~Bq} \cdot \mathrm{L}^{-1}$ for rain water falling through aluminum sheet and between $34-52 \mathrm{~Bq} \cdot \mathrm{L}^{-1}$ with an average of $44 \pm 10$ $\mathrm{Bq} \cdot \mathrm{L}^{-1}$ for rain water falling through asbestos sheet.

For ${ }^{238} \mathrm{U}$, the activity concentration ranged from $2-7$ $\mathrm{Bq} \mathrm{L}{ }^{-1}$ with an average of $4 \pm 2 \mathrm{~Bq} \cdot \mathrm{L}^{-1}$ for well water; 2 $-5 \mathrm{~Bq} \cdot \mathrm{L}^{-1}$ with an average of $3 \pm 1 \mathrm{~Bq} \cdot \mathrm{L}^{-1}$ for tap water; 1 - $12 \mathrm{~Bq} \cdot \mathrm{L}^{-1}$ with an average of $5 \pm 2 \mathrm{~Bq} \cdot \mathrm{L}^{-1}$ for non drinkable surface water; $3-6 \mathrm{~Bq} \cdot \mathrm{L}^{-1}$ with an average of $4 \pm 2 \mathrm{~Bq} \cdot \mathrm{L}^{-1}$ for drinkable surface water; $2-3 \mathrm{~Bq} \cdot \mathrm{L}^{-1}$ with an average of $2 \pm 1 \mathrm{~Bq} \cdot \mathrm{L}^{-1}$ for freely falling rain water; $2-4 \mathrm{~Bq} \cdot \mathrm{L}^{-1}$ with an average of $3 \pm 1 \mathrm{~Bq} \cdot \mathrm{L}^{-1}$ for rain water falling through aluminum sheet and between 3 - $4 \mathrm{~Bq} \cdot \mathrm{L}^{-1}$ with an average of $4 \pm 2 \mathrm{~Bq} \cdot \mathrm{L}^{-1}$ for rain water falling through asbestos sheet.

For ${ }^{232} \mathrm{Th}$, the activity concentration ranged from 2 - 3 $\mathrm{Bq} \cdot \mathrm{L}^{-1}$ with an average of $2 \pm 1 \mathrm{~Bq} \cdot \mathrm{L}^{-1}$ for well water; 2 - $4 \mathrm{~Bq} \cdot \mathrm{L}^{-1}$ with an average of $3 \pm 1 \mathrm{~Bq} \cdot \mathrm{L}^{-1}$ for tap water; $2-10 \mathrm{~Bq} \cdot \mathrm{L}^{-1}$ with an average of $5 \pm 1 \mathrm{~Bq} \cdot \mathrm{L}^{-1}$ for non drinkable surface water; $1-4 \mathrm{~Bq} \cdot \mathrm{L}^{-1}$ with an average of $2 \pm 1 \mathrm{~Bq} \cdot \mathrm{L}^{-1}$ for drinkable surface water, $1-3 \mathrm{~Bq} \cdot \mathrm{L}^{-1}$ with an average of $2 \pm 1 \mathrm{~Bq} \cdot \mathrm{L}^{-1}$ for freely falling rain water; $2-3 \mathrm{~Bq} \cdot \mathrm{L}^{-1}$ with an average of $2 \pm 1 \mathrm{~Bq} \cdot \mathrm{L}^{-1}$ for rain water falling through aluminum sheet and between 2 $-3 \mathrm{~Bq} \cdot \mathrm{L}^{-1}$ with an average of $2 \pm 1 \mathrm{~Bq} \cdot \mathrm{L}^{-1}$ for rain water falling through asbestos sheet.

The largest contribution to the overall activity in all the various types of water sample came mainly from ${ }^{40} \mathrm{~K}$ with the lowest value of $6 \pm 2 \mathrm{~Bq} \cdot \mathrm{L}^{-1}$ and the highest being $177 \pm 52 \mathrm{~Bq} \mathrm{~L}^{-1}$ compared to the activity ranges of (1 - 12) Bq. $\mathrm{L}^{-1}$ and $(1-10) \mathrm{Bq} \cdot \mathrm{L}^{-1}$ for ${ }^{238} \mathrm{U}$ and ${ }^{232} \mathrm{Th}$ respectively. In fact, this can't be a surprise because Potassium-40 is a naturally occurring radionuclide which abounds in the earth crust and in human body $[25,26]$. The specific activity due to ${ }^{232} \mathrm{Th}$ is relatively low in all the water sample investigated. This is because ${ }^{238} \mathrm{U}$ is more mobile than ${ }^{232} \mathrm{Th}$ [27]. The activity concentration

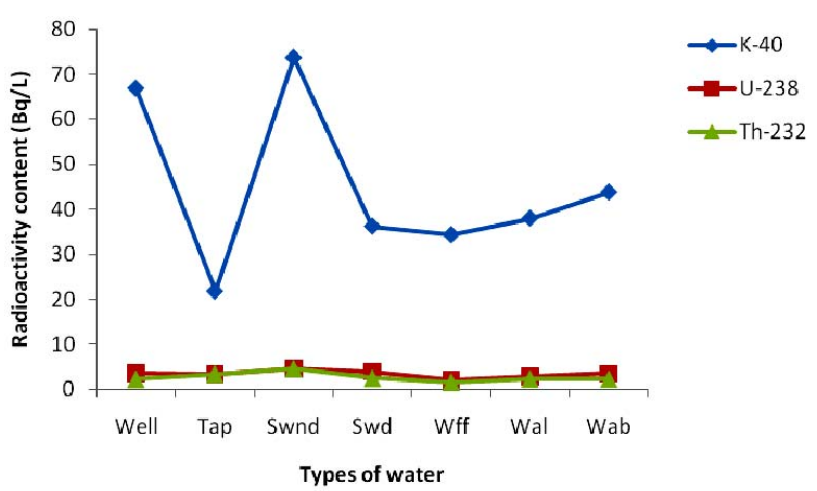

Figure 2. Radioactivity content in various types of water analyzed. 
Table 2. Radioactivity in water sample in Delta State $\left(\mathbf{B q} \cdot \mathbf{L}^{-1}\right)$.

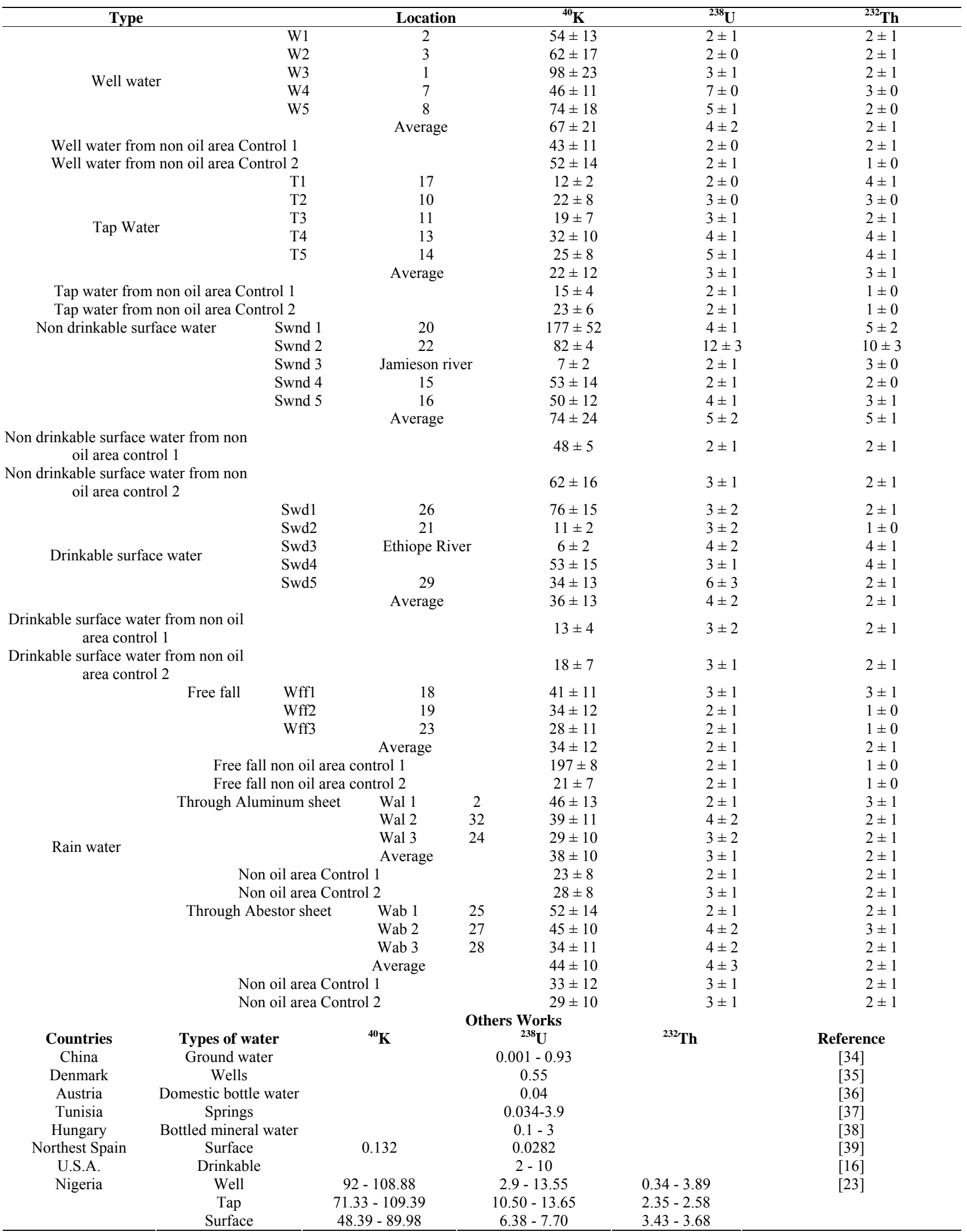


of ${ }^{238} \mathrm{U},{ }^{232} \mathrm{Th}$ and ${ }^{40} \mathrm{~K}$ were relatively higher in non drinkable surface water compared to other types of water. In fact, many of that non drinkable water were stable if not, have a very low flowing speed, and hence accumulated almost all the elements arising from transport and erosion. This trend is also noticeable in well water for ${ }^{40} \mathrm{~K}$.

The overall lowest activity concentration for ${ }^{238} \mathrm{U}$, ${ }^{232} \mathrm{Th}$ and ${ }^{40} \mathrm{~K}$ was obtained in freely falling rain water. This can be predictable since free fall is the first pathway from which all types of water passed through the atmosphere to the earth where more radionuclide contaminants are found. The activity concentration of ${ }^{238} \mathrm{U},{ }^{232} \mathrm{Th}$ and ${ }^{40} \mathrm{~K}$ are higher in rain water collected through asbestos sheet than that of rain water through aluminum sheets. The explanation for this could be found in a recent study by Olomo et al. [4] on the surveying of radionuclide in building materials used for Nigerian dwellings which reported higher activity concentrations of ${ }^{238} \mathrm{U},{ }^{232} \mathrm{Th}$ and ${ }^{40} \mathrm{~K}$ in asbestos as a roofing materials.

Location 20 (Oweh) present the highest activity concentration for ${ }^{40} \mathrm{~K}$ from a non drinkable surface water. That location is an end point of a small tributary of Eriona river where water accumulate during raining- and dry seasons.

Enhanced levels of uranium, thorium and their daughter products might be present in water in areas that have relatively high natural radioactivity. The overall mean specific activity was high in surface water compared to other types of water such as tap and all type of rain water sample. As ground water moves through fractures in the bedrock that contain these deposits of radioactive minerals, the deposits can leach out into the ground water system. Others factors are likely to influence the uranium concentration in natural surface water and ground water [28] such as uranium content of the source rocks, sediments or soils and the processes through which uranium may be leached, the proximity of the water to the uranium source, the degree of hydraulic isolation of the water by fresher surface or ground water, the oxidation state of the water and the concentration of suitable complexing agents, which can increase the solubility of uranium [28].

In addition, no correction was found between the concentration of ${ }^{238} \mathrm{U}$ and ${ }^{232} \mathrm{Th}$. In our investigation, for the majority of cases the concentration of ${ }^{238} \mathrm{U}$ exceeded that of ${ }^{232} \mathrm{Th}$. In fact, the geological and solubility properties of ${ }^{238} \mathrm{U}$ and ${ }^{232} \mathrm{Th}$ are different. Their occurrences in water are determined by several factors such as the geology and their geochemistry [29] which allows them to move easily and to contaminate much of the human's environment. Uranium, in particular, is easily mobilized in ground water and surface water. As a result, uranium and its decay product, radium, enter the water supply through ground water, well water, surface water, streams and rivers.

The high activity concentration may also be attributed to the oil and gas activities. In fact, not only the rock formation that hold oil and gas contain natural radioactive elements, but naturally radioactive elements are dissolved into ground water, and the produced water can accumulate at different points in oils and gas production facilities [30]. Thus, extraction and separation processes stages can have accumulation of radionuclide and some will remain in the water after the processes. This produced water is brought out with oil and gas unavoidably and then leached to the surrounding environment through transport or erosion, resulting to its contamination.

Geologically, the bedrocks are mainly sedimentary made up of sandstones and gravel. They are usually made of grains that are primarily quartz but may contain some potassium containing feldspar. On the whole, they are low in both the series and non-series radionuclide. However, many deposits of uranium are found at the boundary of different layers of sandstones.

Although the results of our investigation are high when compare to that of a non oil and gas areas (control) with similar geology, but still within arrange obtained elsewhere [23].

\subsection{Total Annual Effective Doses from Daily Intakes of ${ }^{238} \mathrm{U},{ }^{232} \mathrm{Th}$ and ${ }^{40} \mathrm{~K}$ from Water}

When analyzing the total annual effective dose to the human population from natural sources, the dose received by ingestion of long-lived natural radionuclide must be considered. Effective doses resulting from intake of ${ }^{238} \mathrm{U}$, ${ }^{232} \mathrm{Th}$ and ${ }^{40} \mathrm{~K}$ may be determined directly from all the water types since some of them are ingested indirectly by man. Assuming the volume of the daily intake of a drinking water for adult male to be $1 \mathrm{~L} \cdot \mathrm{d}^{-1}$ [31], the annual effective dose was calculated with the intake of individual radionuclide and ingestion doses coefficients $\left(\mathrm{Sv} \cdot \mathrm{Bq}^{-1}\right)$ reported by the International Commission on Radiological Protection [32]. The equation for calculating the annual effective dose per person is given by:

The Annual Effective Dose (AED) is given by:

$$
\mathrm{AED}=\sum_{i} \mathrm{I}_{i} \times 365 \times \mathrm{D}_{i}
$$

where $I_{i}$ is the daily intakes of radionuclide $i\left(B q \cdot d^{-1}\right) ; D_{i}$ is the ingestion dose coefficient $\left(\mathrm{Sv} \cdot \mathrm{Bq}^{-1}\right)$.

The results obtained are presented in Table 3 and Figure 3. The derived AED received by the population as a result of the ingestion of ${ }^{238} \mathrm{U}$ in water is estimated to have a range of $0.1-0.7 \mu \mathrm{Sv} \cdot \mathrm{y}^{-1}$ with an average of $0.4 \pm 0.2$ $\mu \mathrm{Sv} \cdot \mathrm{y}^{-1}$ in well water; $0.2-0.5 \mu \mathrm{Sv} \cdot \mathrm{y}^{-1}$ with an average of 
Table 3. Daily intakes ${ }^{40} \mathrm{~K},{ }^{238} \mathrm{U}$ and ${ }^{232} \mathrm{Th}$ and the estimated annual effective doses from water in Delta State, Nigeria.

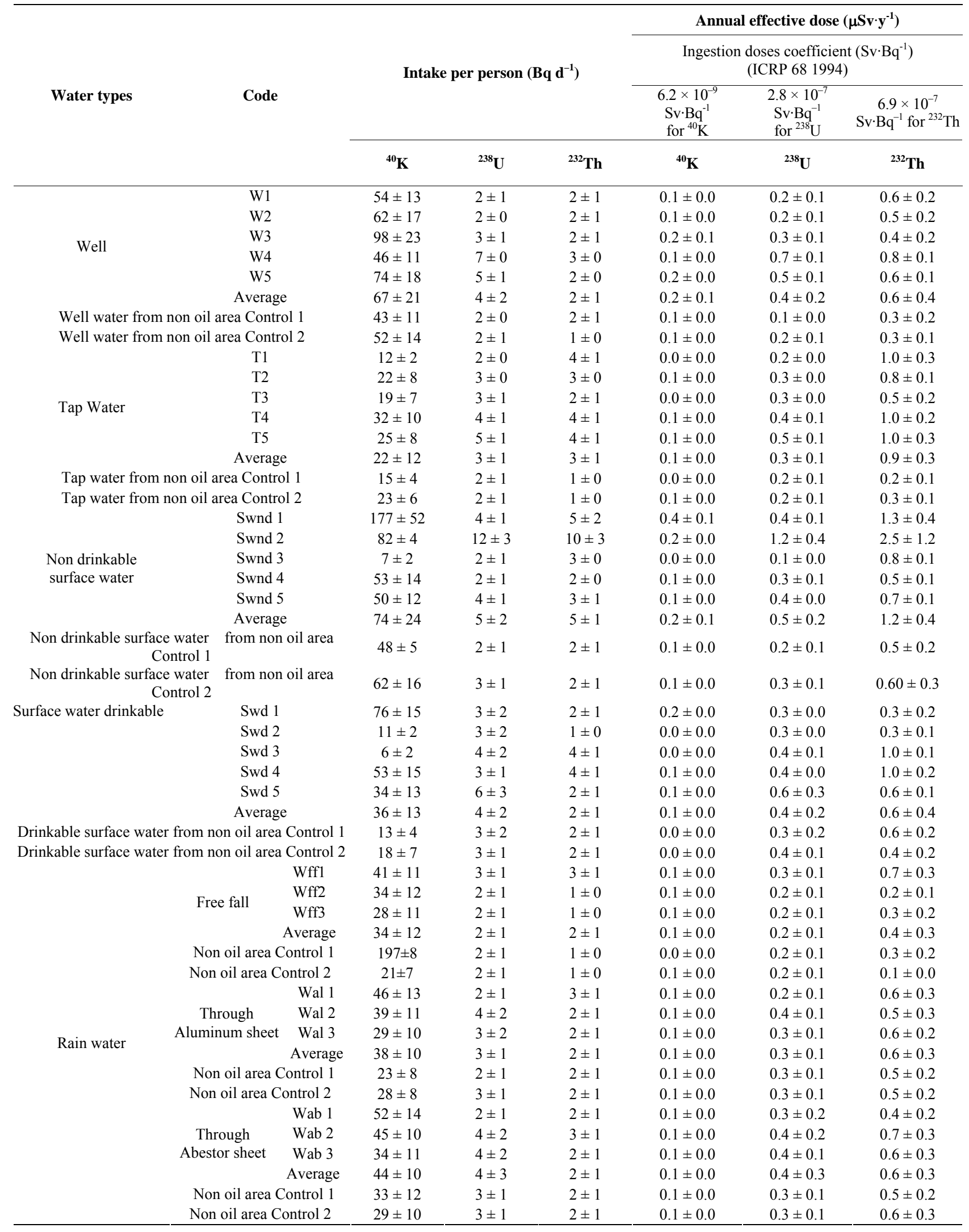




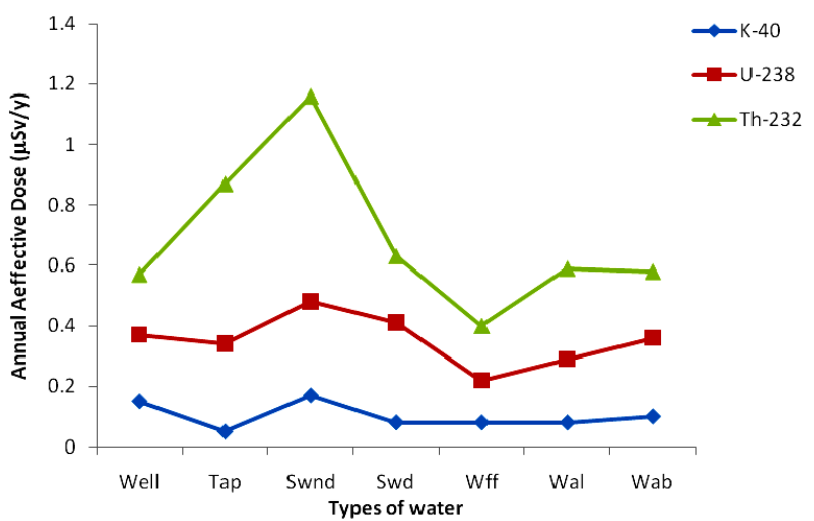

Figure 3. Annual effective dose in various types of water analyzed.

$0.3 \pm 0.1 \mu \mathrm{Sv} \cdot \mathrm{y}^{-1}$ in tap water; $0.1-1.2 \mu \mathrm{Sv} \cdot \mathrm{y}^{-1}$ with an average of $0.5 \pm 0.2 \mu \mathrm{Sv} \cdot \mathrm{y}^{-1}$ in non drinkable surface water, $0.3-0.6 \mu \mathrm{Sv} \cdot \mathrm{y}^{-1}$ with an average of $0.4 \pm 0.2$ $\mu \mathrm{Sv} \cdot \mathrm{y}^{-1}$ in drinkable surface water; $0.2-0.3 \mu \mathrm{Sv} \cdot \mathrm{y}^{-1}$ with an average of $0.2 \pm 0.1 \mu \mathrm{Sv} \cdot \mathrm{y}^{-1}$ in free fall rain water; 0.2 - $0.4 \mu \mathrm{Sv} \cdot \mathrm{y}^{-1}$ with an average of $0.3 \pm 0.1 \mu \mathrm{Sv} \cdot \mathrm{y}^{-1}$ in rain water through aluminum sheets; $0.3-0.4 \mu \mathrm{Sv} \cdot \mathrm{y}^{-1}$ with an average of $0.4 \pm 0.3 \mu \mathrm{Sv} \cdot \mathrm{y}^{-1}$ in rain water through asbestos sheet. While the derived AED received by the population as a result of the ingestion of ${ }^{228} \mathrm{Ra}$ in water is estimated to have a range of $0.1-0.3 \mu \mathrm{Sv} \cdot \mathrm{y}^{-1}$ with an average of $0.2 \pm 0.1 \mu \mathrm{Sv} \cdot \mathrm{y}^{-1}$ in well water; $0.2-0.4 \mu \mathrm{Sv} \cdot \mathrm{y}^{-1}$ with an average of $0.3 \pm 0.1 \mu \mathrm{Sv} \cdot \mathrm{y}^{-1}$ in tap water; 0.2 $0.8 \mu \mathrm{Sv} \cdot \mathrm{y}^{-1}$ with an average of $0.4 \pm 0.1 \mu \mathrm{Sv} \cdot \mathrm{y}^{-1}$ in non drinkable surface water; $0.1-0.3 \mu \mathrm{Sv} \cdot \mathrm{y}^{-1}$ with an average of $0.2 \pm 0.1 \mu \mathrm{Sv} \cdot \mathrm{y}^{-1}$ in drinkable surface water; 0.1 $0.2 \mu \mathrm{Sv} \cdot \mathrm{y}^{-1}$ with an average of $0.2 \pm 0.1 \mu \mathrm{Sv} \cdot \mathrm{y}^{-1}$ in free fall rain water; $0.1-0.2 \mu \mathrm{Sv} \cdot \mathrm{y}^{-1}$ with an average $0.2 \pm$ $0.1 \mu \mathrm{Sv} \cdot \mathrm{y}^{-1}$ in rain water through aluminum sheets; 0.1 $0.2 \mu \mathrm{Sv} \cdot \mathrm{y}^{-1}$ with an average $0.2 \pm 0.1 \mu \mathrm{Sv} \cdot \mathrm{y}^{-1}$ in rain water through asbestos sheets (Table 3). Also the ${ }^{40} \mathrm{~K}$ contribution for the AED was very low when compared with that of ${ }^{238} \mathrm{U}$ and ${ }^{232} \mathrm{Th}$. According to ICRP recommendations [33] the limit for public exposure should be expressed as an effective dose of $1 \mathrm{mSv} \cdot \mathrm{y}^{-1}$. The doses estimated from our investigation are below that limit for all water samples. Although, the water sample with the dose close to that limit is not used for any direct purpose, but it get into soil and can find his way into foods through roots. It is therefore vital to manage it through proper disposal. The lowest AED was found in rain water falling freely and the highest in non drinkable surface water.

\section{Conclusion and Recommendations}

This work is aimed at measuring the concentration of naturally occurring radionuclide as well as man-made ones Cs-137 in community water in oil and gas producing areas in Delta State, Nigeria. The results of the investigation indicated that the average specific activity concentrations of ${ }^{238} \mathrm{U}$ and ${ }^{232} \mathrm{Th}$ and ${ }^{40} \mathrm{~K}$ in community water have consistent values with those reported in other countries in the world. The highest Annual Effective Dose from daily intakes of these radionuclides came from non drinkable surface water. Proper disposable, seasonal and regular monitoring of this type of water, which generally is wastes from industries, should be carrying out.

\section{Acknowledgements}

The authors wish to express their sincere gratitude to the International Atomic Energy Agency who provides standard radioactive sources use for calibration of the detector system, and to the Director, Centre for Energy Research and Development (CERD) Ile-Ife, Osun StateNigeria for making his laboratory available for Gamma Spectrometry analysis.

\section{References}

[1] J. B. Olomo, "The Natural Radioactivity in Some Nigerians Foodstuffs," Nuclear Instruments and Methods in Physics Research A, Vol. 299, No. 1-3, 1990, pp. 666-669. doi:10.1016/0168-9002(90)90866-5

[2] W. Ciezkowski and T. A. Przylibski, "Radon Waters from Health Resorts of the Sudety Mountains (SW Poland)," Applied Radiation and Isotopes, Vol. 48, No. 6, 1997, pp. 855-856. doi:10.1016/S0969-8043(96)00305-3

[3] A. C. Hakonson-Hayes, P. R. Fresquez and F. W. Whicker, "Assessing Potential Risks from Exposure to Natural Uraniumin Well Water," Journal of Environmental Radioactivity, Vol. 59, No. 1, 2002, pp. 29-40. doi:10.1016/S0265-931X(01)00034-0

[4] J. B. Olomo, P. Tchokossa and C. A. Aborisade, "Study of Radiation Protection Guidelines in the Use of Building Materials for Urban Dwellings in South-West Nigeria," Nigerian Journal of Physics, Vol. 15, No. 1, 2003, pp. 7-13.

[5] R. T. Eikelboom, E. Ruwiel and J. J. J. M. Gounmans, "The Building Materials Decree: An Example of a Dutch Regulation Based on the Potential Impact of Materials on the Environment," Waste Management, Vol. 21, No. 3, 2001, pp. 295-302. doi:10.1016/S0956-053X(00)00103-3

[6] C. Namasivayam, R. Radhika and S. Suba, "Uptake of Dyes by a Promising Locally K.S.V., Bapat, V.N., David M. Available Agricultural Solid Waste: Coir Pith," Waste Management, Vol. 21, No. 4, 2001, pp. 381-387. doi:10.1016/S0956-053X(00)00081-7

[7] UNEP/GEMS Environment Library No 5, "The Contamination of Food", 1992.

[8] C. Myttenaere, W. R. Schell, Y. Thriy, L. Sombre, C. 
Ronneau and J. Van Der Stegen De Schrieck, "Modelling of Cs-137 Cycling in Forest: Recent Developments and Research Needed," The Science of the Total Environment, Vol. 136, No. 1-2, 1993, pp. 77-91.

doi:10.1016/0048-9697(93)90298-K

[9] Z. Papp, Z. Dezso and Daroczy, "Significant Radioactive Contamination of Soil around Acoal-Fired Thermal Power Plant," Journal of Environmental Radioactivity, Vol. 59, No. 2, 2002, pp. 191-205. doi:10.1016/S0265-931X(01)00071-6

[10] United Nation Scientific Committee on the Effects of Atomic Radiation (UNSCEAR), "Sources, Effects and Risks of Ionizing Radiation," New York, 1988.

[11] United Nation Scientific Committee on the Effects of Atomic Radiation (UNSCEAR), "Sources and Effects of Ionizing Radiation," New York, 1993.

[12] A. F. Mettler and W. K. Sinclair, "The 1986 and 1988 UNSCEAR Reports: Findings and Implications," Health Physics, Vol. 58, No. 3, 1990, pp. 241-250. doi:10.1097/00004032-199003000-00001

[13] M. K. Fasasi, P. Tchokossa, J. O. Ojo and F. A. Balogun, "Occurrence of Natural Radionuclides and Fallout Cesium-137 in Dry-Season Agricultural Land of South Western Nigeria," Journal of Radioanalytical and $\mathrm{Nu}$ clear Chemistry, Vol. 240, No. 3, 1999, p. 949. doi:10.1007/BF02349880

[14] O. A. Osibote, J. B. Olomo, P. Tchokossa and F. A. Balogun, "Radioactivity in Milk Consumed in Nigeria Ten Years after Chernobyl Reactor Accident," Nuclear Instruments and Methods in Physics Research A, Vol. 422, No. 1-3, 1999, pp. 778-783. doi:10.1016/S0168-9002(98)00996-6

[15] C. R. Cothern and W. L. Lappenbusch, "Occurrence of Uranium in Drinking Water in the U.S.," Health Physics, Vol. 45, 1983, pp. 89-99. doi:10.1097/00004032-198307000-00009

[16] C. R. Cothern and W. L. Lappenbusch and M. Jacqueline, "Drinking-Water Contribution to Natural Background Radiation," Health Physics, Vol. 50, 1986, pp. 33-47. doi:10.1097/00004032-198601000-00002

[17] C. T. Hess, J. Michel, T. R. Horton, H. M. Prichard and W. A. Coniglio, "The Occurrence of Radioactivity in Public Water Supplies in the United States," Health Physics, Vol. 48, 1983, pp. 553-586. doi:10.1097/00004032-198505000-00002

[18] T. R. Horton, "Methods and Results of EPA's Study of Radon in Drinking Water," EPA 520/5-83-037, Eastern Environmental Research Facility, U.S. EPA Office of Radiation Programs, Montomery, 1984.

[19] D. Laugmur and J. S. Hermanm, "The Mobility of Thorium in Natural Water at Low Temperatures," Geochimica et Cosmochimica Acta, Vol. 44, No. 11, 1980, pp. 1753-1766. doi:10.1016/0016-7037(80)90226-4

[20] J. Michel and W. S. Moore, “'228 Ra and ${ }^{226} \mathrm{Ra}$ Content of Ground Water in Fall Line Acquifers," Health Physics, Vol. 38, 1980, pp. 663-671. doi:10.1097/00004032-198004000-00014

[21] T. A. Przylibski and A. Zebrowski, "Origin of Radon in Medicinal Waters of Ladek Zdroj (Susety Mountains, SW Poland)," Journal of Environmental Radioactivity, Vol. 46, No. 1, 1999, pp. 121-129. doi:10.1016/S0265-931X(98)00116-7

[22] J. B. Olomo, M. K. Akinloye and F. A. Balogun, "Distribution of Gamma-Emitting Natural Radionuclides in Soils and Water around Nuclear Research Establishments, Ile-Ife, Nigeria," Nuclear Instruments and Methods in Physics Research A, Vol. 353, No. 1-3, 1994, pp. 553557. doi:10.1016/0168-9002(94)91721-3

[23] P. Tchokossa, J. B. Olomo and O. A. Osibote, "Radioactivity in the Community Water Supplies of Ife-Central and Ife-East Local Government Areas of Osun State, Nigeria," Nuclear Instruments and Methods in Physics Research A, Vol. 422, No. 1-3, 1999, pp. 784-789. doi:10.1016/S0168-9002(98)00997-8

[24] International Atomic Energy Agency (IAEA), "Measurements of Radionuclides in Food and the Environment," A guidebook, Technical Report Series No. 295, IAEA, Vienna, 1989

[25] International Commission on Radiological Protection (ICRP), "Limits for Intakes of Radionuclides by Workers," ICRP Publication 30, Vol. 4, No. 3-4, 1980, pp. 11-12.

[26] International Commission on Radiological Protection (ICRP), "Principles for Limiting Exposure of the Public to Natural Sources of Radiation," ICRP Publication 39, Vol. 14, No. 1, 1984, p. 17.

[27] National Council on Radiation Protection and Measurements (NCRP), "Exposure of the Population in the United States and Canada from Natural Background Radiation," NCRP Report No 94, Bethesda MD 20814, 1987.

[28] D. Langmuir, "Uranium Deposits," Mineralogy and Origin, Handbook 3, 1978.

[29] J. Molinari and W. J. Snodgrass, "The Chemistry and Radiochemistry of Radium and the Other Elements of the Uranium and Thorium Natural Decay Series," The Environmental Behavior of Radium, IAEA 1, 1990, pp. 1-56.

[30] A. S. Paschoa, "Naturally Occurring Radioactive Materials (NORM) and Petroleum Origin," Applied Radiation and Isotopes, Vol. 48, No. 10-12, 1997, pp. 1391-1396. doi:10.1016/S0969-8043(97)00134-6

[31] World Health Organisation, "Guidelines for Drinking Water Quality,” 2nd Edition, Vol. 1, 1993, pp. 114-121.

[32] International Commission on Radiological Protection, (ICRP), "Doses Coefficients for Intake of Radionuclides by Workers: Replacement of ICRP Publication 61," Pergamon Press, Oxford, ICRP Publication 68, 1994.

[33] International Commission on Radiological Protection, (ICRP), "1990 Recommendations of the International Commission on Radiological Protection," Annals of ICRP, ICRP Publication 60, Vol. 21, No. 1-3, 1991, pp. 1-201.

[34] Z. Weihai, I. Takao and X. T. Y., "Occurrence of Rn-222, Ra-226, Ra-228 and U in Groundwater in Fujian Province, 
China," Journal of Environmental Radioactivity, Vol. 53, 2001, pp. 11-120.

[35] K. Ulback and O. Klinder, "Radium and Radon in Danish Drinking Water," Radiation Protection and Dosimetry, Vol. 7, No. 1-4, 1984, pp. 87-89.

[36] C. Kralik, M. Friedrich and F. Vojir, "Natural Radionuclides in Bottled Water in Austria," Journal of Environmental Radioactivity, Vol. 65, 2003, pp. 233-241. doi:10.1016/S0265-931X(02)00099-1

[37] S. Labidi, M. Dochraoui, Mahjoubi, N. B. Lemaitre, R. Salah and S. Mtimet, "Natural Radioactive Nuclides in Some Tunisian Thermo-Mineral Springs," Journal of En- vironmental Radioactivity, Vol. 62, 2002, pp. 8-96. doi:10.1016/S0265-931X(01)00153-9

[38] J. Somlai, G. Horvath, B. Kanyar, T. Kovacs, E. Bodrogi and N. Kavasi, "Concentration of Ra-226 in Hungarian Bottled Mineral Water," Journal of Environmental Radioactivity, Vol. 62, 2002, pp. 235-240. doi:10.1016/S0265-931X(01)00166-7

[39] L. I. Pujol and J. A. Sandez-Cabeza, "Natural and Artificial Radioactivity in Surface Waters of the Ebro River Basin (Northeast Spain)," Journal of Environmental Radioactivity, Vol. 51, No. 2, 2000, pp. 181-210. doi:10.1016/S0265-931X(00)00076-X 